\title{
A revision of the trionychid turtle Procyclanorbis sardus Portis, 1901 from the late Miocene of Sardinia (Italy)
}

\author{
Une révision de la tortue trionychidé Procyclanorbis sardus Portis, 1901 du \\ Miocène supérieur de Sardaigne (Italie) \\ Georgios L. Georgalis ${ }^{\mathrm{a}, \mathrm{b}, *}$, Daniel Zoboli ${ }^{\mathrm{c}}$, Gian Luigi Pillola ${ }^{\mathrm{c}}$, Massimo Delfino $^{\mathrm{b}, \mathrm{d}}$ \\ a Department of Geosciences, University of Fribourg, 6, chemin du Musée, 1700 Fribourg, Switzerland \\ b Dipartimento di Scienze della Terra, Università di Torino, 35, via Valperga Caluso, 10125 Torino, Italy \\ c Dipartimento di Scienze Chimiche e Geologiche, Università di Cagliari, 51, via Trentino, 09127 Cagliari, Italy \\ d Institut Català de Paleontologia Miquel Crusafont, Universitat Autònoma de Barcelona, Edifici ICTA -ICP, Carrer de les Columnes s/n, Campus de la UAB, \\ 08193 Cerdanyola del Vallès, Barcelona, Spain
}

Keywords:

Procyclanorbis

Trionychidae

Sardinia

Miocene

Insularity

\section{Introduction}

Procyclanorbis sardus Portis, 1901 is the first named fossil soft-shelled turtle from the island of Sardinia, Italy (Portis, 1901a). This taxon has had a problematic taxonomic history, being

\footnotetext{
* Corresponding author. Department of Geosciences, University of Fribourg Chemin du Musée 6, 1700 Fribourg, Switzerland.

E-mail address: georgios.georgalis@unifr.ch (G.L. Georgalis).
}

\begin{abstract}
A B S T R A C T
Procyclanorbis sardus Portis, 1901 is the first fossil trionychid turtle described from Sardinia. This late Miocene taxon was originally considered to have affinities with the African and southern Asian cyclanorbines. We here redescribe in detail the holotype specimen of this species, which has suffered severe degradation since its original publication. A comparison between the original state of the fossil and its current state of preservation is provided. On the basis of its anatomy, affinities of Procyclanorbis sardus with cyclanorbines are discarded and this taxon is demonstrated to be an indeterminate pan-trionychine. The distribution of fossil trionychids in the Mediterranean Islands is also discussed.
\end{abstract}

\begin{abstract}
R É S U M É
Procyclanorbis sardus Portis, 1901 est la première tortue trionychidé fossile décrite en Sardaigne. Ce taxon du Miocène supérieur a été initialement considéré comme ayant des affinités avec les cyclanorbines d'Afrique et d'Asie du Sud. Nous décrivons ici en détail et figurons l'holotype de cette espèce, qui a subi une importante dégradation depuis sa publication originale. Une comparaison entre l'état originel du fossile et son état de conservation actuel est fournie. Sur la base de son anatomie, les affinités de Procyclanorbis sardus avec les cyclanorbinés sont rejetées car ce taxon s'avère être un pantrionychiné indéterminé. La distribution des trionychidés fossiles dans les îles de la Méditerranée est également discutée.
\end{abstract}


Institutional Abbreviations: MDLCA: Museo Sardo di Geologia e Paleontologia “Domenico Lovisato", Cagliari, Italy.

\section{Material and methods}

The holotype carapace of Procyclanorbis sardus is curated, along with its natural mold, at MDLCA under the collection number MDLCA 14007. Other specimens (another carapace, a skull, and additional plastral elements) that were also originally referred to P. sardus by Portis (1901a) could not be located and we agree with Kotsakis (1985) that they were probably destroyed during World War II. The partial carapace of a trionychid, also from the type area, that was subsequently referred to P. sardus by Comaschi Caria (1959) is also housed in the collections of MDLCA under the number MDLCA 14008.

\section{Geological setting}

The Calcari di Cagliari Formation (Gandolfi and Porcu, 1967; Cherchi, 1974) carbonate succession is represented by three main lithofacies which are, from the bottom to top: "PietraCantone", "Tramezzario" and "Pietra Forte". Note that the names, informally adopted in the most recent official geological map (Barca et al., 2005), are derived from the names used by quarrymen.

The "Pietra Cantone" is composed of a stratified yellow marlyarenaceous limestone with common intense bioturbation. The intermediate lithofacies ("Tramezzario") is represented by whitish calcarenites, is locally marly and bears abundant bioclastic components, and shows widespread phenomena of synsedimentary breccias, slumpings, erosional surfaces and faulting. The "Pietra Forte" represents mainly the top of the succession and consists of massive coarse bioclastic (mainly rodalgal-mollusc) biostromallimestones [for further details on lithology and facies distribution see Barca et al. (2005)].

The Calcari di Cagliari Formation is considered to be late Miocene in age (Kotsakis, 1985; Zoboli and Pillola, 2016). The Tortonian/Messinian boundary is tentatively placed within the upper part of the "Pietra Cantone" (Cherchi A., personal communication, 2016).

The holotype carapace with its internal mold, as also the referred skull and plastral elements described by Portis (1901a) and now lost, as also the referred carapace imprint described by Comaschi Caria (1959), were all found in the Is Mirrionis area in Cagliari. The associated reptile fauna from Is Mirrionis consists only of the type material of the crocodylian Tomistoma calaritanum Capellini, 1890.

The entire area of Is Mirrionis and the adjacent Tuvixeddu and Tuvumannu hills and Sant'Avendrace, currently inhabited but with several outcrops and sections still cropping-out, was intensively quarried for building materials since historical times. The studied material originates, in most likelihood, from the lower "Tramezzario" facies; therefore, we tentatively assign a Messinian age to these remains.

\section{Historical background}

Portis (1901a) originally established the new species Procyclanorbis sardus on the basis of an incomplete carapace and its mold from the late Miocene of Is Mirrionis, Cagliari and Sardinia. The same author additionally referred to the same species a rather complete but crushed skull and two plastral fragments from the same locality, as also another, partial carapace from the late Miocene of Sassari, near Nulvi, northern Sardinia (Portis, 1901a). On the basis of all this material, and mostly the morphology of the nuchal and the costals, Portis (1901a) considered Procyclanorbis sardus to be the first European member of Pan-Cyclanorbinae, a clade that has extant representatives only in Africa and southern Asia, and, at that time, a poor fossil record confined to few finds in the Indian subcontinent (Lydekker, 1885, 1889). Portis (1901a) also envisaged similarities of his new Sardinian pan-trionychid with certain Central European finds, more specifically with Trionyx gergensi Reinach von, 1900 from the early Miocene of Germany and Trionyx preschenensis Laube, 1900 from the early Miocene of the Czech Republic. He furthermore considered this resemblance as adequate enough to suggest congeneric affinities between the Sardinian, German and Czech specimens, therefore recombining both $T$. gergensi and T. preschenensis into his new genus Procyclanorbis, and thereby treating them as the northernmost occurrences of pan-cyclanorbines known to that date (Portis, 1901a).

Since then, only few mentions of Procyclanorbis sardus have occurred in the chelonian literature. Furthermore, besides sporadic simple mentions of just the name (e.g. Bergounioux, 1954; Kotsakis and Palombo, 1979; Comaschi Caria, 1986; Kotsakis, 1989; Karl, 1999), only few authors have dealt with the taxonomic affinities of the Sardinian taxon. Fucini (1912) was the first to express doubts on the validity of the genus Procyclanorbis and stated that $P$. sardus could only be differentiated from Trionyx pliocenicus Fucini, 1912 from the Pliocene of Tuscany, Italy, on the basis of minor morphological characters. Few years later, Hummel $(1929,1932)$ defied Portis's (1901a) original identification of the Sardinian material as a cyclanorbine and he rather included it into Amyda, recombining it as Trionyx (Amyda) sardus. Such subgeneric assignment was a common practice for most European fossil trionychids according to Hummel (1929), who erroneously also referred Trionyx triunguis to Amyda. Bergounioux (1935) mentioned the presence of the otherwise Czech taxon Trionyx pontanus Laube, 1895, in the Miocene of Sardinia without providing any other information, but it is now believed that this is rather an error, and that this author intended to mean instead Trionyx sardus (Georgalis and Joyce, 2017). In the same paper, Bergounioux (1935) mentioned that P. sardus was also known from Switzerland, again most probably an error. Comaschi Caria (1959) later described new trionychid remains from the Miocene of Sardinia. The new finds originated from the Miocene localities of Is Mirrionis (type locality of $P$. sardus) and Sant'Avendrace, with the author assigning them to P. sardus and the Oligocene French taxon Trionyx burdigalensis Bergounioux, 1935, respectively, but treating both species as members of Amyda (Comaschi Caria, 1959). Few years later, in his compendium, Kuhn (1964) continued to treat $P$. sardus as a pan-trionychine and a member of Trionyx. Broin (1977) made a brief mention of $P$. sardus stating that the referred skull that was originally described by Portis (1901a) belonged in fact to a cheloniid marine turtle. In his review of the Italian trionychids, Kotsakis (1985) followed the opinion of Broin (1977) that the referred skull does not belong to trionychids, further mentioning that this specimen was probably lost (destroyed during the World War II), and he tentatively treated all Miocene finds from Sardinia as pertaining to one species, $P$. sardus, which he considered as a member of Trionyx. Delfino (2002) followed Kotsakis (1985) and reported $P$. sardus as a tentative valid species of Trionyx. Chesi (2009) also considered P. sardus as a member of Trionyx but noted that the validity of this taxon should be tested using a modern systematic approach. He further described new Sardinian finds from the early Miocene locality of Noragugume, which he treated as an indeterminate pan-trionychid (Chesi, 2009). In their review of the Miocene reptiles housed at the MDLCA, Zoboli and Pillola (2016) mentioned $P$. sardus and provided a new figure of the actual preservation state of the holotype specimen. They additionally showed that the carapace referred to $T$. burdigalensis by Comaschi Caria (1959) is in fact a cheloniid, and this specimen is not located in a museum, but is a walled part of a fountain in Sant'Avendrace (Cagliari). In their overview of all Old World fossil pan-trionychids, Georgalis and Joyce (2017) briefly discussed the 
status of $P$. sardus on the basis of its published descriptions. They considered that the referred skull and plastral elements belong in fact to cheloniids, whereas the holotype carapace and the other two referred carapaces of Portis (1901a) and Comaschi Caria (1959) represent indeterminate pan-trionychines. As such, Procyclanorbis sardus was considered to be a nomen dubium (Georgalis and Joyce, 2017).

\section{Systematic paleontology}

Class: Reptilia Laurenti, 1768

Order: Testudines Batsch, 1788

Family: Trionychidae Gray, 1825

Sub-Family: Pan-Trionychinae Georgalis and Joyce, 2017

\section{Pan-Trionychinae indet. (Figs. 1-3)}

Synonymy:

1901a Procyclanorbis sardus Portis: Plate 1 Plate 1.

1912 Procyclanorbis sardus Portis: Fucini, 1912, p. 3.

1929 Trionyx sardus Portis: Hummel, 1929, p. 25.

1954 Procyclanorbis sardus Portis: Bergounioux, 1954, p. 191.

1959 Amyda sardus Portis: Comaschi Caria, 1959, p. 38.

1977 Procyclanorbis sardus Portis: Broin 1977, p. 191.

1979 Procyclanorbis sardus Portis: Kotsakis and Palombo, 1979, p. 624.
1983 Trionyx sardus Portis: Esu and Kotsakis, 1983, p. 198.

1986 Amyda sarda Portis: Comaschi Caria, 1986, p. 29.

Description of the holotype:

Portis (1901a) described both the carapace and its internal mold, but figured only the former specimen. Judging from the published figure (Fig. 1) and the current preservation state of this specimen (Fig. 2), it seems that it has suffered a lot of damage since its original description. Indeed, the carapace is much better preserved in Plate 1.1 of Portis (1901a), while currently the posterior half of the specimen is almost totally missing. Such damage was probably caused during the World War II, although Portis (1901a) already mentioned that the whole turtle material from Is Mirrionis had suffered damage during the transport from Cagliari to Turin, where the author was based at that time.

Judging from the published figure and the original description, where the specimen appears more complete (Fig. 1a), it seems that the holotype pertains to a medium-sized trionychid, with a carapace length of about $45 \mathrm{~cm}$. The margins of the carapace, however, are universally not preserved. Especially, the latter margin is severely deformed, rendering the size of last costals ambiguous. There is no preneural. The nuchal is rather enlarged and sits anterior to the disc formed by the costals. There are seven neurals. The first two neurals are large and elongated, especially neural I which is also relatively wide. It is not possible to determine whether there is a reversal in the neural orientation, as is the typical condition
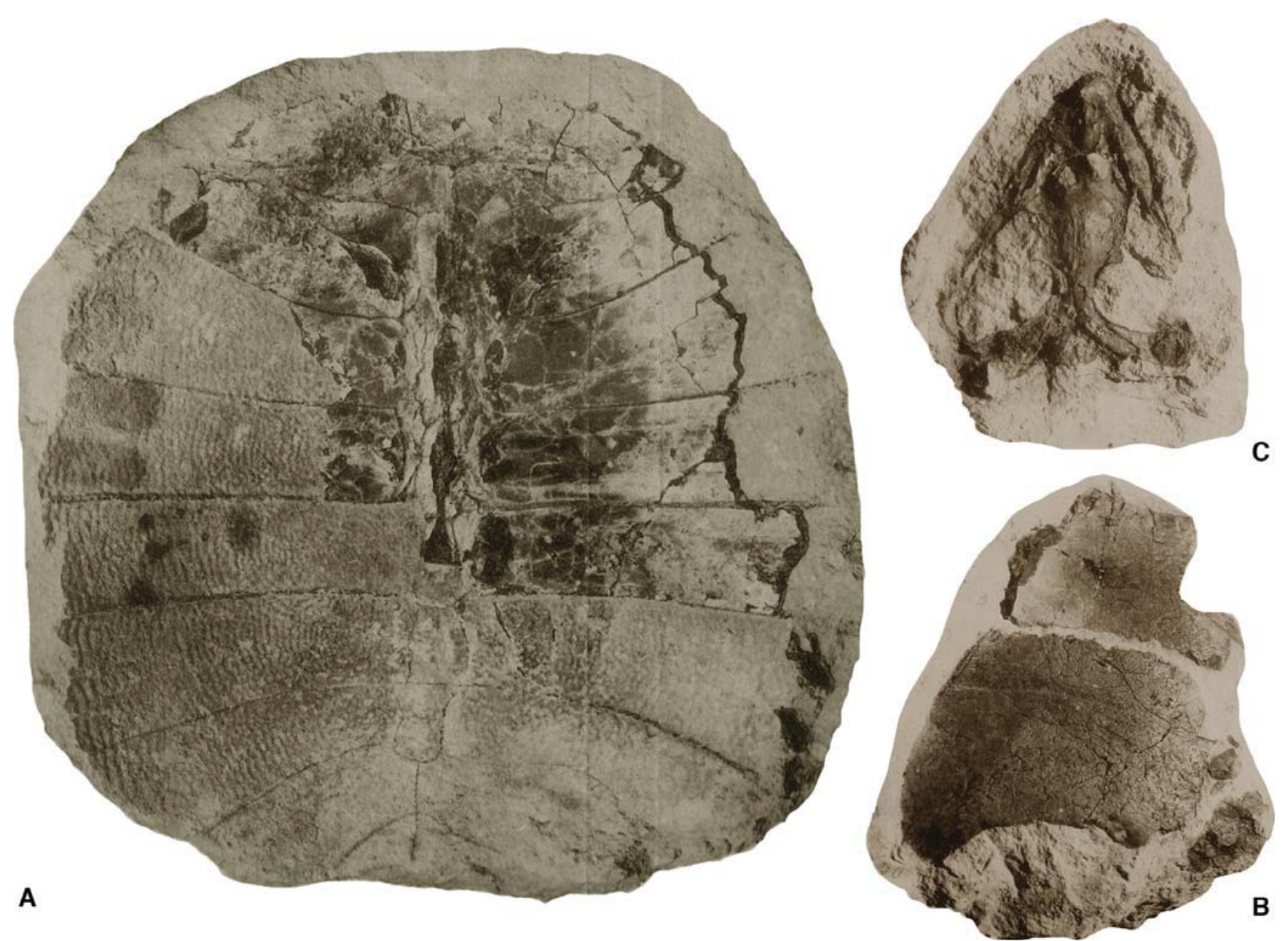

Fig. 1. The original plate of Portis (1901a) with the holotype carapace of Procyclanorbis sardus and the referred plastral and cranial material. A. The holotype carapace. B. The now lost partial left hyo-hypoplastron (now identified as a probable cheloniid). C. The now lost skull (now identified as a probable cheloniid).

Planche originale de Portis (1901a) avec l'holotype de Procyclanorbis sardus (Carapace) et le matériel référé (plastron et crâne). A. Carapace, holotype. B. Hyo-hypoplastron gauche aujourd'hui perdu (maintenant identifié comme un chéloniidé probable). C. Crâne aujourd'hui perdu (maintenant identifié comme un chéloniidé probable). 

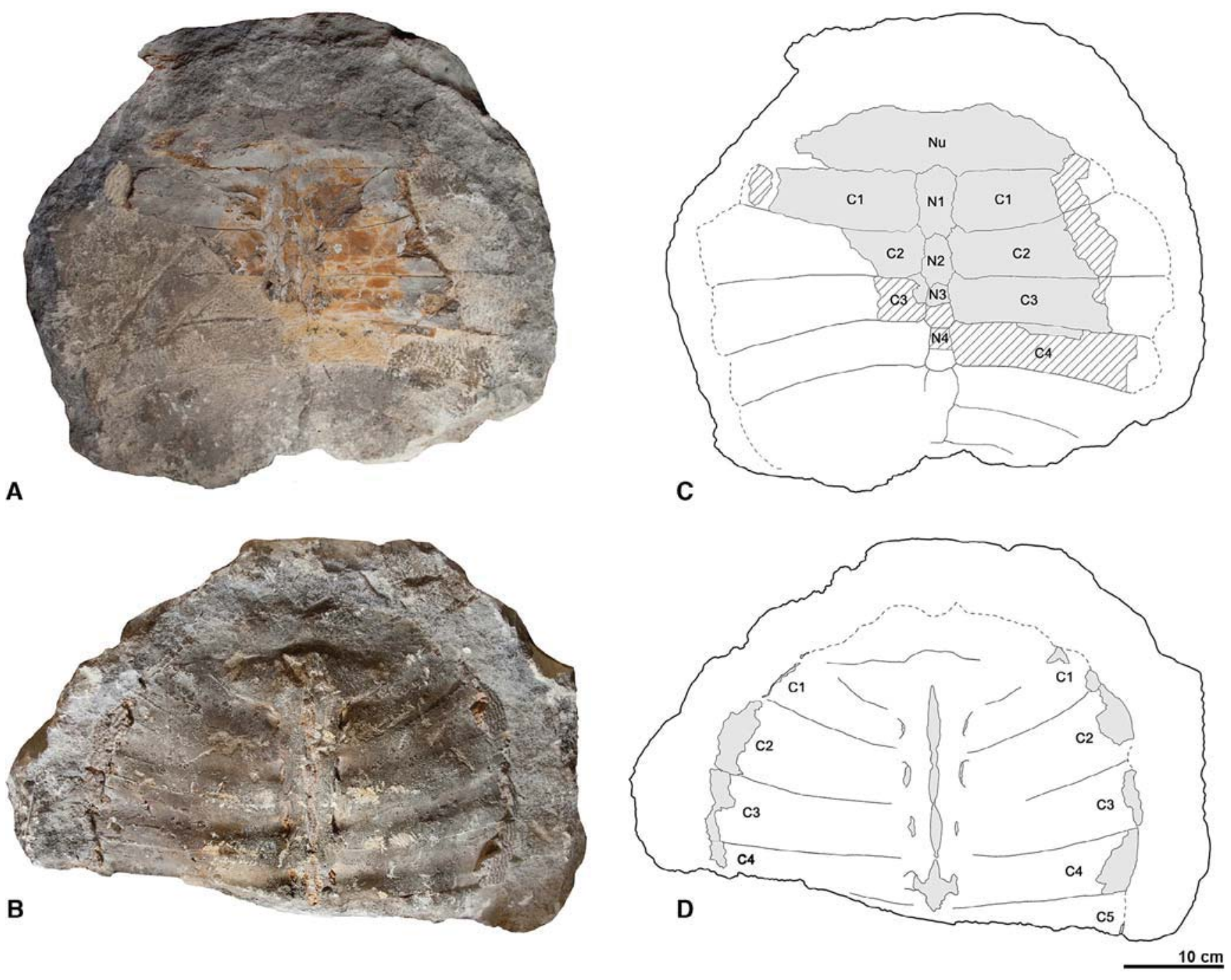

Fig. 2. The current state of preservation of the holotype partial carapace (MDLCA 14007) of Procyclanorbis sardus (A, C) and its imprint (B, D). Abbreviations: Nu-nuchal, N1-N4-neurals I-IV, C1-C5-costals I-V.

État de conservation actuel de l'holotype (carapace partielle) (MDLCA 14007) de Procyclanorbis sardus (A, C) et son empreinte (B, D). Abréviations : Nu - nucale, N1-N4 - neurales $I-I V, C 1-C 5$ - costales $I-V$.

for pan-trionychines (Meylan, 1987). The last neural meets at the midline costals VI and the anteriormost part of costals VII. There are eight pairs of costals. Costals are relatively large, with costals II being distally expanded, whereas costals VIII seem to be reduced and short and fully meet at the midline of the carapace. However, the reduced size of costals VIII should be taken with caution, due to the breakage at the posterior margin of the carapace. The sculpturing pattern consists of a network of ridges at the lateral margins of the carapace, whereas it slightly fades towards the center of the shell, consisting mostly of small tubercles at the neural region. The sculpturing in the nuchal region has been totally faded out and it is impossible to state the nature of that pattern at this region of the shell.

In the current and severely damaged form, only the anterior part of the carapace is preserved (Fig. 2). As such, only the nuchal, the first four neurals, the first four right and first three left costals can be observed, whereas in its natural mold, remnants of the nuchal and the first five left and four right costals are preserved (Fig. 2). Of course, the visible preserved features in the imprint should not be taken into full consideration, as they do not reliably reflect the external arrangement of the bones (Georgalis and Joyce, 2017). Indeed the size, shape and inclination of all preserved costals are radically different from those observed in the actual carapace. The sculpturing pattern is currently not well preserved, and it appears that it has severely faded out (Fig. 3).

\section{Discussion}

6.1. Taxonomic identification and status of Procyclanorbis sardus

A vast number of trionychid taxa have been named from the European Miocene, in particular from the central and southern parts of the continent (Georgalis and Joyce, 2017). The validity of the majority of these species has been recently rejected by Georgalis and Joyce (2017), who demonstrated the presence of two different pan-trionychid lineages in the European Miocene, belonging to the extant pan-trionychine genera Rafetus and Trionyx. According to these authors, only differences in the number and extent of sculpturing callosities on the plastron is a reliable character for discriminating fossils of these two lineages based on shell material, and minor carapacial characters among Rafetus and Trionyx, such as differences in the size of the last costals, should be better considered tentative and variable. Furthermore, the presence of pan-cyclanorbines in the European fossil record was recently discarded, as the European purported member of this clade, Trionyx 


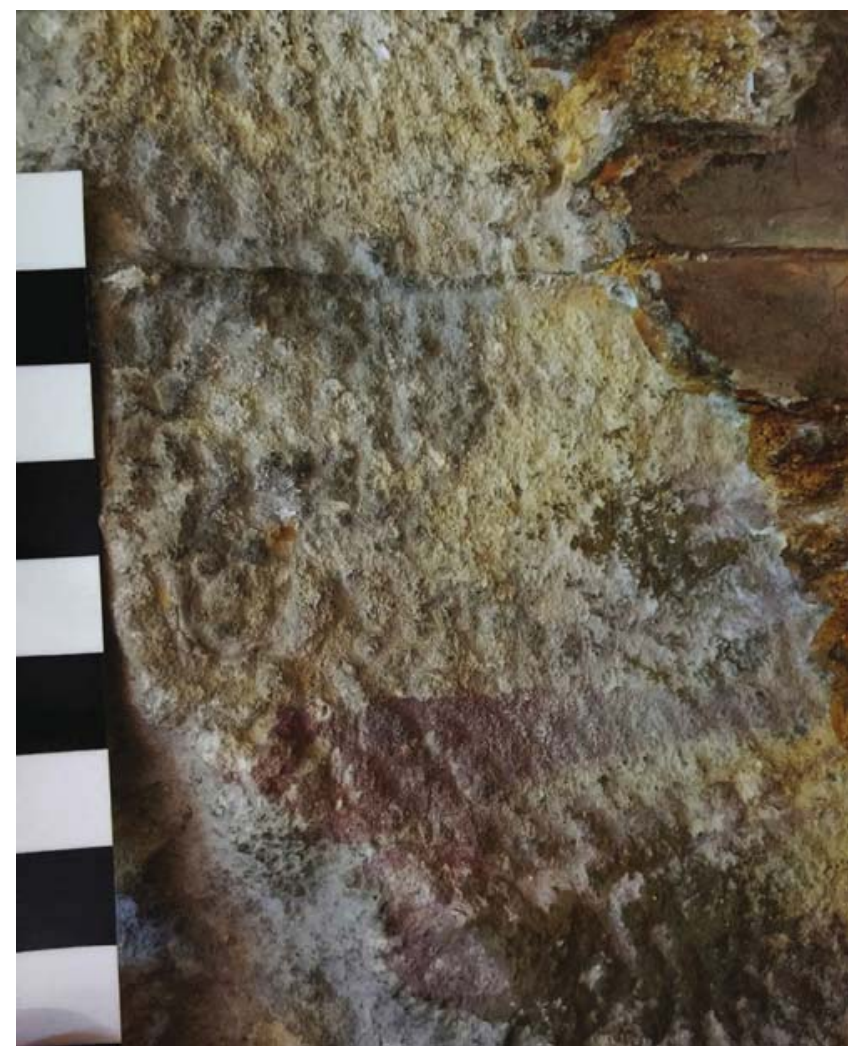

Fig. 3. A close up of the sculpturing pattern of MDLCA 14007 (holotype of Procyclanorbis sardus).

Vue rapprochée sur l'ornementation de la carapace MDLCA 14007 (holotype de Procyclanorbis sardus).

melitensis Lydekker, 1891, from the Miocene of Malta, was shown to be in fact a cheloniid (Georgalis and Joyce, 2017; see below). Therefore, only material containing plastral elements could be adequately assigned to either Rafetus or Trionyx. The identification of the now lost partial hyo-hypoplastron referred to $P$. sardus by Portis (1901a) as a probable cheloniid (see below), leaves the Sardinian form as a carapace based only taxon. For this reason, in addition with the incomplete nature of the holotype, P. sardus has to be considered to be a nomen dubium, pertaining an indeterminate pan-trionychine.

Portis (1901a) envisaged his new species Procyclanorbis sardus as pertaining to cyclanorbines. He noted strong resemblance with the extant African cyclanorbine genera Cyclanorbis and Cycloderma, whereas among extinct taxa, Procyclanorbis sardus was most similar with Trionyx gergensi and T. preschenensis, for which he formally suggested congeneric affinities with his new Sardinian form (Portis, 1901a). However, all such affinities were proposed on the basis of highly variable characters, such as the sculpturing pattern and the shape and size of costals and neurals (Meylan, 1987; Vitek and Joyce, 2015). Furthermore, the type carapace of $P$. sardus can be readily excluded from Pan-Cyclanorbinae by the absence of a preneural and the lack of split costiform processes on the nuchal (Meylan, 1987). Additionally, the carapacial sculpturing of $P$. sardus is not so prominent as that of extant cyclanorbines. Furthermore, the suggestion of Hummel $(1929,1932)$ and Comaschi Caria (1959) that the Sardinian taxon belongs to Amyda, is also attributed to highly homoplastic and variable characters and the latter genus should be confined only to Asian forms. In particular, judging from the carapace morphology, it seems most probable that $P$. sardus belongs to the same lineage with trionychines, although the absence of plastral material prevents any definite conclusion. Exact affinities with the three valid pan-trionychid taxa from the Neogene of Europe, Rafetus bohemicus (Liebus, 1930), from the Miocene of the Czech Republic, Trionyx vindobonensis Peters, 1855, from the Miocene of central and western Europe, and Trionyx pliocenicus Fucini, 1912, from the Pliocene of Italy, cannot be made with certainty due to the absence of plastral material for the Sardinian taxon. As was stated above, the holotype carapace of $P$. sardus seems to bear rather small costals VIII, a common feature of the Rafetus lineage. However, the damaging of the posterior margins of the carapace hinders the exact shape and size of these elements, and we are therefore reluctant to make any generic assignment of the Sardinian form. As such, the fact that there is no reliable plastral material, in addition with the incomplete nature of the holotype and its unfortunate subsequent severe damaging, prompt us to consider Procyclanorbis sardus to be a nomen dubium.

Regarding the skull that was originally referred to Procyclanorbis sardus by Portis (1901a), this specimen is now lost, but it was at least figured. Broin (1977) and subsequently Esu and Kotsakis (1983) and Kotsakis (1985) considered that this specimen does not belong to pan-trionychids, but instead it has cheloniid affinities. Indeed, judging from the published image of this specimen (Fig. 1c), it seems that the skull did not belong to pan-trionychids: its basicranium appears to be extremely slender (and not broad as in most pantrionychids) and possibly also, prepalatine foramina are present (which are totally absent in pan-trionychids).

The plastral fragments that were originally referred by Portis (1901a) to Procyclanorbis sardus correspond to a partial left hyohypoplastron. This material is also lost, probably during the World War II. In any case, judging from the published figure of the original publication (Fig. 1b), and the shape and the size of the hyohypoplastron, it seems that these elements also pertain to a marine turtle. Indeed, even in the original description, Portis (1901a) admitted that at first glance this plastral material seemed to pertain to a cheloniid, but after his subsequent study he denoted strong resemblance with the plastron of the extant African cyclanorbines Cyclanorbis and Cycloderma. Pan-cyclanorbine hyo-hypoplastra are characterized by their fusion soon after hatchling (Meylan, 1987). Portis (1901a) also stated the presence of sculpturing on the hyohypoplastron, though this character could not be evaluated in the accompanying image of the specimen. On the basis of the only existing and poor quality figure, the plastral elements referred to $P$. sardus seem to have stronger resemblance to cheloniids rather than that of any pan-trionychid.

As for the putative, now lost, carapace from Sassari, Portis (1901a) only briefly described this specimen, without figuring it, stating that this specimen was smaller than the holotype and apparently pertained to a younger individual. Fortunately, however, the partial carapace imprint from the type locality described by Comaschi Caria (1959) as referable to P. sardus is still located in the collections of MDLCA under the accession number 14008. However, this specimen also has suffered severe degradation since its original description (Fig. 4). Although it was initially an almost complete imprint of a carapace, missing only its upper right and lower margins of the shell, in its current state of preservation, large parts of the carapace imprint are missing and the edges of most costals have faded. We consider this specimen as well to be an indeterminate pan-trionychine, on the basis of the absence of peripherals and shell scutes.

\subsection{Trionychids from the Mediterranean Islands}

As evidenced by the fossil record, soft-shelled turtles variously occurred in the Mediterranean islands (Georgalis and Joyce, 2017). This clade has no extant representatives in the Mediterranean islands, although living individuals of Trionyx triunguis have been repeatedly reported from the Dodecanese Islands in Greece, 


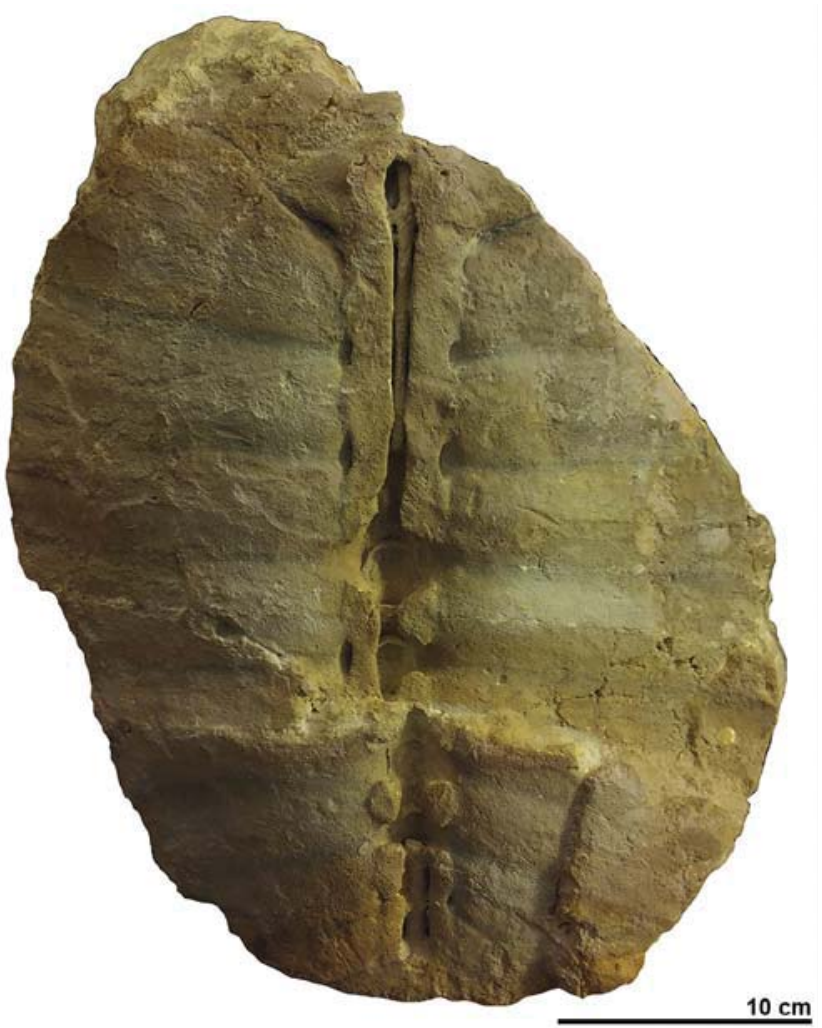

Fig. 4. The current state of preservation of the trionychid referred to Procyclanorbis sardus by Comaschi Caria (1959) (MDLCA 14008).

État de conservation actuel du trionychidé rapporté à Procyclanorbis sardus par Comaschi Caria (1959) (MDLCA 14008).

specifically Kos, Symi, Leros, Kalymnos and Rhodes, some kilometers away from the southwestern coast of Asia Minor (Corsini-Foka and Masseti, 2008). However, these sightings of living individuals of T. triunguis should be better considered as random cases of marine dispersals across narrow straights of the Aegean Sea, as this species has been well documented to swim at certain marine distances from the coast (Taskavak et al., 1999). Nevertheless, most fossil finds from this region are rather fragmentary, hindering the exact taxonomic affinities of the Mediterranean Islands pan-trionychids. Such remains have been found in the Eocene of the Balearic Islands (Mallorca; Jiménez Fuentes et al., 1990) and Sardinia (Kotsakis, 1985), and the Miocene of Cyprus (Reed, 1932; Hadjisterkotis et al., 2000), Crete (Georgalis et al., 2016), Sicily (De Gregorio, 1883), and of course Sardinia. Among these, only the Miocene Sardinian and Sicilian material has been identified at the species level, with the two supposedly endemic taxa Procyclanorbis sardus and Trionyx ragusensis De Gregorio, 1883, respectively. The latter occurrence is rather problematic, as the only known specimen is lost and has never been figured, and therefore, T. ragusensis should better be considered a nomen dubium (Georgalis and Joyce, 2017). Curiously, pan-trionychids are totally absent from the well-known Miocene faunas of the Aegean Islands (Georgalis and Kear, 2013), with the exception of Crete, from where they were only recently described (Georgalis et al., 2016). Additionally, their total absence from Corsica seems bizarre, as pan-trionychids are abundant in the late Paleogene and Neogene of southern France and northwestern and central western Italy (e.g. Portis, 1879, 1883; Ristori, 1895; Bergounioux, 1933). The case of Malta is intriguing, as from that island, Lydekker (1891) established Trionyx melitensis, a purported trionychid that was either assigned to cyclanorbines (Lapparent de Broin and Van Dijk, 1999), Trionyx sensu lato (Kotsakis, 1985), or the Asian Nilssonia lineage (Hummel, 1929). However, Georgalis and
Joyce (2017) recently showed that the holotype and only known specimen of $T$. melitensis pertains to a cheloniid, and more specifically to Trachyaspis or a Trachyaspis-like genus, a marine turtle that is characterized by a distinctive sculpturing pattern. Other purported occurrences of fossil trionychids from Malta (Gulia, 1843; Cooke, 1890) most probably pertain to the same individual, the holotype of T. melitensis (Zammit-Maempel, 1979). Accordingly, the holotype of $P$. sardus remains the most complete fossil pantrionychid specimen from the Mediterranean Islands.

Of course the paleogeography of the Mediterranean Islands was totally different during the Paleogene and the Neogene, with certain islands either connected with the European and African mainland or emerging only more recently (Esu and Kotsakis, 1983; Rögl, 1999). This fact inevitably hinders our understanding of the Mediterranean Islands trionychids, and it cannot be known with certainty if they represent indeed insular forms or are simply representatives of continental taxa. The scarceness of fossil trionychids from North Africa (Georgalis and Joyce, 2017) also hampers this situation, although few complete finds clearly denote the presence of the Trionyx triunguis lineage already in that region (Wood, 1987). In the case of Sardinia and Procyclanorbis sardus, during the Tortonian-Messinian the Sardo-Corsican Massif and the Tuscany area formed an archipelago of islands, isolated from continental Europe (Casanovas-Vilar et al., 2011). This insular paleobioprovince comprised a highly unique island vertebrate fauna, as it is testified by fossils recovered from the Fiume Santo locality (Portotorres, northwestern Sardinia), which include the primate Oreopithecus and several peculiar bovids and rodents (Abbazzi et al., 2008b). Consequently, we suggest that $P$. sardus was an insular taxon. Subsequently, the Sardinia-Corsica area was isolated from Tuscany by the mid-late Messinian due to the opening of the Tyrrhenian Sea (Palombo, 2009).

\section{Conclusions}

The holotype shell of Procyclanorbis sardus Portis, 1901a, is described herein and the taxonomic status of this species is reevaluated. New and detailed figures of the holotype (including interpretative drawings), which has suffered severe damaging since its original description, are provided. Affinities of $P$. sardus with cyclanorbines are discarded on the basis of its shell anatomy, and the Sardinian taxon clearly belongs to trionychines. However, a referral to either Rafetus or Trionyx, the trionychine lineages that are present in the Miocene of Europe, is currently not possible. The skull and the hyo-hypoplastron that were originally referred to $P$. sardus by Portis (1901a), belong in fact to cheloniid turtles. Procyclanorbis sardus is considered to be an indeterminate pan-trionychine and the name is considered a nomen dubium. However, even if it does not bear distinctive diagnostic features, the holotype specimen of $P$. sardus represents the best-preserved trionychid fossil from the Mediterranean Islands.

Despite a conspicuous fossil record (Delfino, 2002; Chesi et al., 2007; Chesi, 2009), the only valid turtle species from Sardinia is therefore Testudo pecorinii Delfino, 2008 that was described on the basis of a complete shell from the Early Pleistocene of the D4 local fauna of Capo Mannu (Abbazzi et al., 2008a). The status of nomen dubium for the trionychid turtle Procyclanorbis sardus Portis, 1901a follows that of Palaeopython sardus Portis, 1901, whose holotype was originally referred to a pythonid snake (Portis, 1901b), but that is in fact an indeterminate acanthomorphan fish (Delfino et al., 2014). Similarly, we planned the revision of Tomistoma calaritanum Capellini, 1890, because is not clear if this species, originally described in two papers published in the same year (Capellini, 1890a, b) is valid or not (see Kotsakis et al., 2004, and Piras et al., 2007, and literature therein) and the type was severely damaged 
during the World War II, and therefore few morphological characters are left for its revision. The revision of type materials and the retrieval of new remains from the type or neighboring localities [not always possible but very useful; see Zoboli et al. (2016) for a recent example concerning a Sardinian monkey] is mandatory to reassess the validity of taxa that were erected in the late nineteenth or early twentieth century by enthusiastic paleontologists that knew very well the literature, but had little direct familiarity with the morphology and variation of extant and extinct reptiles (Delfino et al., 2014).

\section{Disclosure of interest}

The authors declare that they have no competing interest.

\section{Acknowledgements}

We would like to thank Walter Joyce (University of Fribourg) for useful comments that improved the quality of the manuscript. We also thank our editor Romain Vullo (CNRS Géosciences Rennes) and our reviewers Julien Claude (Institut des sciences de l'évolution de Montpellier) and Adán Pérez-García (Grupo de Biología Evolutiva, Facultad de Ciencias, UNED, Madrid) for their valuable help during the Editorial and Reviewing process. MD was supported by Fondi di Ateneo dell'Università di Torino (2015-2016), Generalitat de Catalunya (2014 SGR 416 GRC and CERCA Program) and Spanish Ministerio de Economía y Competitividad (CGL2016-76431-P). DZ acknowledges the Sardinia Regional Government for financial support of PhD scholarship (P.O.R. Sardegna F.S.E. Operational Programme of the Autonomous Region of Sardinia, European Social Fund 2007-2013 - Axis IV Human Resources, Objective 1.3, Line of Activity 1.3.1.). GLP was supported by "Contributo Ateneo per la Ricerca" of the Cagliari University.

\section{References}

Abbazzi, L., Carboni, S., Delfino, M., Gallai, G., Lecca, L., Rook, L., 2008a. Fossil vertebrates (Mammalia and Reptilia) from Capo Mannu (Late Pliocene, Western Sardinia, Italy) with description of a new Testudo (Chelonii Testudinidae) species. Rivista Italiana di Paleontologia e Stratigrafia 114, 119-132.

Abbazzi, A., Delfino, M., Gallai, G., Trebini, L., Rook, L., 2008b. New data on the vertebrate assemblage of Fiume Santo (North-West Sardinia Italy) and overview on the Late Miocene Tusco-Sardinian palaeobioprovince. Palaeontology 52, 251-425.

Barca, S., Melis, E., Annino, E., Cincotti, F., Ulzega, A., Orrù, P., Pintus, C., 2005. Note Illustrative della Carta Geologica d'Italia alla scala 1:50.000. In: Foglio 557 “Cagliari". Servizio Geologico d'Italia, Regione Autonoma della Sardegna, S.EL.CA, Firenze.

Bergounioux, F.M., 1933. Monographie paléontologique de la faune de vertébrés des sables de Montpellier 2. Chéloniens fossiles des sables Pliocènes astiens de Montpellier. Travaux du Laboratoire de Géologie de la Faculté des sciences de Lyon 23, 1-32

Bergounioux, F.M., 1935. Contribution à l'étude paléontologique des chéloniens: chéloniens fossiles du bassin d'Aquitaine. Mémoires de la Société Géologique de France 25, 1-215.

Bergounioux, F.M., 1954. Les chéloniens fossiles des terrains tertiaires de la Vénétie. Memorie degli Istituti di geologia e mineralogia del l'Università di Padova 18, $1-115$.

Broin, F. de, 1977. Contribution à l'étude des Chéloniens : Chéloniens continentaux du Crétacé et du Tertiaire de France. Mémoires du Muséum National d'Histoire Naturelle, Série C, 38., pp. 1-366.

Capellini, G., 1890a. Sul coccodrilliano garialoide (Tomistoma calaritanus) scoperto nella collina di Cagliari nel 1868. Rendiconti della Reale Accademia dei Lincei, serie 4 6, 149-151.

Capellini, G., 1890b. Sul coccodrilliano garialoide (Tomistoma calaritanus) scoperto nella collina di Cagliari nel MDCCCLXVIII. Atti della Reale Accademia Lincei, Memorie della Classe di Scienze Fisiche. Matematiche e Naturali, serie 46 , 507-533.

Casanovas-Vilar, I., Dam, J.A., van, Trebini, L., Rook, L., 2011. The rodents from the Late Miocene Oreopithecus-bearing site of Fiume Santo (Sardinia, Italy). Geobios 44, 173-187.

Cherchi, A. 1974. Appunti biostratigrafici sul Miocene della Sardegna (Italia) Actes V Congrès du Néogene Méditerranée Lyon 1971. Mémoire du Bureau de Recherches Géologiques et Minières 78, pp. 433-445.
Chesi, F., (PhD dissertation) 2009. Il registro fossile italiano dei cheloni. Università di Firenze, Florence (Unpublished).

Chesi, F., Delfino, M., Abbazzi, L., Carboni, S., Lecca, L., Rook, L., 2007. New fossil vertebrate remains from San Giovanni di Sinis (Late Pleistocene, Sardinia): the last Mauremys (Reptilia Testudines) in the Central Mediterranean. Rivista Italiana di Paleontologia e Stratigrafia 113, 287-297.

Comaschi Caria, J., 1959. Nuovi resti di cheloni nel Miocene della Sardegna. Bollettino della Società Geologica Italiana 78, 37-44.

Comaschi Caria, I., 1986. Animali e piante fossili della Sardegna. (Terza edizione ampliata e con un guida breve allo studio della Paleontologia). Edizioni della Torre, Cagliari.

Cooke, J.H., 1890. Notes on the fossil reptiles of Malta. Il Naturalista Maltese 1, 18-20.

Corsini-Foka, M., Masseti, M., 2008. On the oldest record of the Nile soft-shelled turtle, Trionyx triunguis (Forskal, 1775), in the Eastern Aegean islands (Greece). Zoology in the Middle East 43, 108-110.

De Gregorio, A., 1883. Nuovi fossili terziari (vertebrati e invertebrati). Palermo.

Delfino, M., (PhD dissertation) 2002. Erpetofaune italiane del Neogene e del Quaternario. University of Modena and Reggio Emilia, Modena and Reggio Emilia (Unpublished)

Delfino, M., Zoboli, D., Carnevale, G., Pillola, G.L., 2014. The rediscovered holotype of Palaeopython sardus Portis, 1901 from the Miocene of Sardinia belongs to a fish, not a snake. Bollettino della Società Paleontologica Italiana 53, 89-92.

Esu, D., Kotsakis, T., 1983. Les vertébrés et les mollusques continentaux du Tertiaire de la Sardaigne : paléobiogéographie et biostratigraphie. Geologia Romana 22, $177-206$.

Fucini, A., 1912. Trionyx pliocenicus Law. Paleontographia Italica 18, 1-28.

Gandolfi, R., Porcu, A., 1967. Contributo alla conoscenza delle microfacies mioceniche delle colline di Cagliari (Sardegna). Rivista Italiana di Paleontologia e Stratigrafia $73,313-348$.

Georgalis, G.L., Joyce, W.G., 2017. A review of the fossil record of Old World turtles of the clade Pan-Trionychidae. Bulletin of the Peabody Museum of Natural History 58, 115-208.

Georgalis, G.L., Kear, B.P., 2013. The fossil turtles of Greece: an overview of taxonomy and distribution. Geobios 46, 299-311.

Georgalis, G.L., Villa, A., Vlachos, E., Delfino, M., 2016. Fossil amphibians and reptiles from Plakias, Crete: a glimpse into the earliest late Miocene herpetofaunas of southeastern Europe. Geobios 49, 433-444.

Gray, J.E., 1825. A synopsis of the genera of reptiles and amphibia, with a description of some new species. Annals of Philosophy 10, 193-217.

Gulia, G., 1843. Guscio di testuggine fossile trovato a Malta. Repertorio di Conoscenze Utile Zoologia Fossile 27, 77-78.

Hadjisterkotis, E., Kassapis, I., Klerides, N., 2000. Paleontological evidence for the presence of Trionyx sp. on Cyprus, with new information on living and alien species of terrapins. Newsletter, Hellenic Zoological Society 33, 8-10.

Hummel, K., 1929. Die fossilen Weichschildkröten (Trionychia): eine morphologisch-systematische und stammesgeschichtliche Studie. Geologische und Paläontologische Abhandlungen 16, 359-487.

Hummel, K., 1932. Pars 52: Trionychia fossilia. In: Quenstedt, W. (Ed.), Fossilium Catalogus. I: Animalia. W. Junk, Berlin.

Jiménez Fuentes, E., Ramos Guerrero, E., Martín De Jesús, S., Pérez Ramos, E., Mulas Alonso, E., 1990. Quelonios del Eoceno medio de Mallorca. Paleontologia i Evolució 23, 153-156.

Karl, H.V., 1999. Die Zoogeographie der känozoischen Weichschildkröte Trionyx triunguis Forskål, 1775 (Testudines: Trionychidae). Joannea - Geologie und Paläontologie 1, 27-60.

Kotsakis, T., 1985. Les Trionychidae (Testudinata Reptilia) fossiles de l'Italie. Bollettino della Società Paleontologica Italiana 24, 161-168.

Kotsakis, T., 1989. Late Turolian amphibians and reptiles from Brisighella (northern Italy): preliminary report. Bollettino della Societa Palaeontologica Italiana 28 277-280.

Kotsakis, A., Delfino, M., Piras, P., 2004. Italian Cenozoic crocodilians: taxa, timing and palaeobiogeographic implications. Palaeogeography, Palaeoclimatology, Palaeoecology 210, 67-87.

Kotsakis, T., Palombo, M.R., 1979. Vertebrati continentali e paleogeografia della Sardegna durante il Neogene. Annales Géologiques des Pays Helléniques. Tome Hors Série 2, 621-630.

Kuhn, O., 1964. Part 107, Testudines. In: Kuhn, O. (Ed.), Fossilium Catalogus, Volume I: Animalia. W. Junk, The Hague.

Lapparent de Broin, F., Van Dijk, P.P., 1999. Chelonia from the Late Miocene Baynunah Formation, Emirate of Abu Dhabi, United Arab Emirates: palaeogeographical implications. In: Whybrow, P.J., Hill, A. (Eds.), Fossil Vertebrates of Arabia. Yale University Press Yale, pp. 136-162.

Laube, G.C., 1895. Vorläufiger Bericht über Schildkrötenreste aus der böhmischen Braunkohlenformation. Verhandlungen der Geologischen Bundesanstalt 1895 391-392.

Laube, G.C., 1900. Neue Schildkröten und Fische aus der böhmischen Braunkohlenformation. Lotos 2, 37-56.

Liebus, A., 1930. Neue Schildkröten aus den Tertiären Süsswassertonen von Preschen bei Bilin in Böhmen. Rozpravy Státního geologického ústavu Československé Republiky 4, 1-57.

Lydekker, R., 1885. Indian Tertiary and post-Tertiary Vertebrata. Siwalik and Nerbada Chelonia. Memoirs of the Geological Survey of India, 21., pp. 155-208.

Lydekker, R., 1889. Notes on Siwalik and Narbada Chelonia. Records of the Geological Survey of India 22, 56-58. 
Lydekker, R., 1891. On a new species of Trionyx from the Miocene of Malta and a chelonian scapula from the London Clay. The Quarterly Journal of the Geological Society of London 47, 37-40.

Meylan, P.A., 1987. The phylogenetic relationships of soft-shelled turtles (Family Trionychidae). Bulletin of the American Museum of Natural History 186, 1-101.

Palombo, M.R., 2009. Biochronology, paleobiogeography and faunal turnover in western Mediterranean Cenozoic mammals. Integrative Zoology 4, 367-386.

Peters, K.F., 1855. Schildkrötenreste aus den österreichischen Tertiärablagerungen. Denkschriften der Kaiserlichen Akademie der Wissenschaften, mathematischnaturwissenschaftliche Classe 9, 1-22.

Piras, P., Delfino, M., Del Favero, L., Kotsakis, T., 2007. Phylogenetic position of the crocodylian Megadontosuchus arduini (de Zigno, 1880) and tomistomine palaeobiogeography. Acta Palaeontologica Polonica 52, 315-328.

Portis, A., 1879. Di alcuni fossili terziarii del Piemonte e della Liguria appartenenti all'ordine dei chelonii. Memorie della Reale Accademia delle Scienze di Torino, serie 2, 2., pp. 113-134.

Portis, A., 1883. Nuovi chelonii fossili del Piemonte. Memorie della Reale Accademia delle Scienze di Torino, serie 2, 35.,pp. 369-378.

Portis, A., 1901a. Il Procyclanorbis sardus Port., nuovo trionychide fossile della Sardegna. Bollettino della Società Geologica Italiana 20, 51-79.

Portis, A., 1901b. Il Palaeopython sardus Port. Nuovo pitonide del Miocene medio della Sardegna. Bollettino della Società Geologica Italiana 20, 247-253.

Reed, F.R.C., 1932. New Miocene faunas from Cyprus. Geological Magazine 69, 511-517.

Reinach von, A., 1900. Schildkrötenreste im Mainzer Tertiärbecken und in benachbarten ungefähr gleichaltrigen. Abhandlungen der Senckenbergischen Naturforschenden Gesellschaft 28, 1-135.
Ristori, G. 1895. Cheloniani fossili di Montebamboli e Casteani. Memoria paleontologica del prof. Giuseppe Ristori. Con appendice sui Cheloniani fossili del Casino (Siena), 21. Pubblicazioni del Reale Istituto di Studi superiori in Firenze, lezione di scienze fisiche e naturale, pp. 1-104.

Rögl, F., 1999. Mediterranean and Paratethys. Facts and hypotheses of an Oligocene to Miocene paleogeography (short overview). Geologica Carpathica 50, 330-349

Taskavak, E., Reimann, M.J., Polder, W.N., 1999. First record of the Nile soft-shelled Turtle, Trionyx triunguis, from Kos Island, Greece, with comments on its occurrence in the eastern Mediterranean. Chelonian Conservation and Biology 3. 510-512.

Vitek, N.S., Joyce, W.G., 2015. A review of the fossil record of New World turtles of the clade Pan-Trionychidae. Bulletin of the Peabody Museum of Natural History $56,185-244$.

Wood, R.C., 1987. Fossil turtles from the Sahabi Formation. In: Boaz, T., El-Amauti, A., Gaziry, A.W., de Heinzelin, J., Dechant Boaz, D. (Eds.), Neogene Palaeontology and Geology of Sahabi. Alan R. Liss, New York, pp. 107-112.

Zammit-Maempel, G., 1979. The Indo-Pacific affinity of some Maltese Tertiary fossils. The Central Mediterranean Naturalist 1, 1-12

Zoboli, D., Pillola, G.L., 2016. I rettili miocenici conservati nel Museo Sardo di Geologia e Paleontologia Domenico Lovisato (Cagliari, Italia). Museologia Scientifica nuova serie $10,81-87$.

Zoboli, D., Pillola, G.L., Rook, L., 2016. New remains of Macaca majori Azzaroli, 1946 (Primates, Cercopithecidae) from Is Oreris (Fluminimaggiore, southwestern Sardinia). Bollettino della Società Paleontologica Italiana 55, 227-230. 